(науковий керівник - кандидат сільськогосподарських наук I. М. Мерленко)

Поліська дослідна станція Національного наукового центру «Інститут грунтознавства та агрохімії імені О. Н. Соколовського»

\title{
ФОРМУВАННЯ ПОКАЗНИКІВ БІОПРОДУКТИВНОСТІ МОРКВИ СТОЛОВӦ̈ ПІД ВПЛИВОМ ОРГАНІЧНОГО ФЕРМЕНТОВАНОГО ДОБРИВА ТА МІКРОБІОЛОГІЧНОГО ПРЕПАРАТУ
}

\section{Рецензент - кандидат сільськогосподарських наук М. І. Зінчук}

Досліджено вплив ферментованого органічного добрива та мікробіологічного препарату «Азотер» на рівень урожайності моркви столової та якість отриманої продукції. Встановлено достовірне підвищеення урожаю коренеплодів (на 26,0-38,4\%) під час внесення органічного ферментованого добрива $(11 \mathrm{~m} / 2 \mathrm{a})$, інтегрованого його застосування $(5,5 \mathrm{~m} / 2 \mathrm{a})$ з мікробіологічним препаратом, а також за обробки трунту препаратом на фоні азотних добрив $\left(N_{30}\right)$. У разі використання досліджуваних систем удобрення відмічено покращання якісних показників коренеплодів культури - спостерігається зростання вмісту каротину, а рівень нітратів не перевищує гранично допустимих кониентрацій.

Ключові слова: морква столова, ферментоване органічне добриво, мікробіологічний препарат, урожайність, якість.

Постановка проблеми. Морква столова є однією 3 найцінніших овочевих культур, оскільки іiі коренеплід містить багатий набір вітамінів та інших біологічно активних речовин, а листя ефірні масла та флавоноїди. Особливою цінністю культури є високий вміст каротиноїдів. Задля формування високоякісного врожаю культури необхідною $є$ оптимальна забезпеченість усіма факторами життя (світло, тепло, волога, повітря, поживні речовини та ін.). Однією з вирішальних умов підвищення біопродуктивності моркви, особливо на бідних дерново-підзолистих грунтах, $\epsilon$ наявність достатньої кількості поживних речовин у доступній для рослин формі, що досягається за рахунок внесення добрив.

Сучасна зацікавленість світової та вітчизняної спільноти безпечними продуктами харчування, i в тому числі овочевою продукцією, вимагає від аграрного виробництва розроблення науково обгрунтованих систем удобрення сільськогосподарських культур (безпосередньо і моркви столової), з повною або частковою відмовою від синтетичних добрив, пестицидів, регуляторів росту, шкідливих домішок тощо. Такі системи удобрення повинні бути безпечними для навколишнього середовища, сприяти підвищенню врожайності культур з одночасним покращанням якісних показників. Вагома роль у виконанні цих завдань належить органічним добривам та мікробіологічним препаратам.

Аналіз останніх досліджень і публікацій, у яких започатковано дослідження проблеми. Питанню підвищення біопродуктивності моркви столової шляхом застосування органічних добрив та мікробіологічних препаратів присвячено чимало наукових праць. Зокрема, у дослідженнях А. В. Бикіна (2000), Т. В. Стрельцової (2000) та В. А. Гаврилюка (2010) відмічено зростання врожайності коренеплодів на 21,9 т/га, 31,2 т/га та 8,2 т/га відповідно за внесення 9 т/га вермикомпосту на темно-сірому опідзоленому грунті, 40 т/га біогумусу на чорноземі звичайному та 15 т/га ферментованого органічного добрива на дерново-підзолистому грунті $[1,6,4]$. Обробка насіння моркви столової біопрепаратом БайкалEM дає змогу підвищити iі врожайність на 2,5 т/га [3]. Бортнік А. М. (2008) наголошує на високій ефективності поєднання біопрепаратів («Агат-25», «Байкал-ЕМ») та ферментованого органічного добрива $(\mathrm{N}-1,2 \%$; $\mathrm{P}-1,2 \%$; $\mathrm{K}$ $0,54 \%$, норма внесення $10 \mathrm{~T} /$ га), що забезпечує приріст урожайності в межах 78,5-77,9\% до контролю [2]. В літературі наголошується, що застосування органічних добрив та мікробіологічних препаратів призводить до посилення синтезу біологічно цінних речовин (каротину та цукрів), й сприяє підвищенню вмісту сухої речовини в коренеплодах [5].

Проте не досить вивченим залишається питання ефективності використання мікробіологічних препаратів у комплексі з органічними та мінеральними добривами. Разом із тим, їх інтегроване застосування під час вирощування моркви столової, могло б значно знизити дози внесення останніх, що є особливо важливим у нинішніх 


\section{СТОРІНКА МОЛОДОГО ВЧЕНОГО}

умовах за недостатнього виробництва традиційних та значних економічних витрат на виготовлення альтернативних видів органічних добрив, а також у разі постійного зростання цін на мінеральні туки. Крім того, застосування даного агрозаходу дає можливість оптимізувати живлення рослин, оскільки завдяки бактеризації забезпечується активніше засвоєння та залучення до конструктивного метаболізму біогенних елементів, що призводить до збільшення вмісту складних органічних речовин в отриманій продукції. Зважаючи на вищесказане, доцільним під час вирощування моркви столової є використання систем удобрення, що передбачають застосування мікробіологічного препарату в комплексі з органічними або мінеральними добривами.

Мета і завдання досліджень. Метою досліджень $є$ встановлення впливу систем удобрення за участю ферментованого органічного добрива та мікробіологічного препарату «Азотер» на показники біопродуктивності моркви столової.

Основним завданням досліджень було визначення урожайності культури та основних показників біохімічного складу їі коренеплодів, сформованих під дією удобрення.

Матеріали і методи досліджень. Вивчення впливу органічного ферментованого добрива (ОФД) та мікробіологічного препарату на врожайність та якісні показники моркви столової були здійснені на базі Поліської дослідної станціï Національного наукового центру «Інститут грунтознавства та агрохімії імені О.Н. Соколовського». Польові досліди проводили в умовах Західного Полісся, на землях Велимчанської сільської ради Ратнівського району Волинської області за наступною схемою:

1. Без добрив (контроль);

2. $\mathrm{N}_{100} \mathrm{P}_{60} \mathrm{~K}_{120}$ (рекомендована норма);

3. Перегній - 18 т/га (1,0 норми від вмісту $\mathrm{N}$ y варіанті 2);

4. Ферментоване органічне добриво - 5,5 т/га

(0,5 норми від вмісту $\mathrm{N}$ у варіанті 2);

5. Ферментоване органічне добриво - 5,5 т/га + «Азотер» 10 л/га;

6. Ферментоване органічне добриво - 5,5 т/га + «Азотер» 10 л/га $+\mathrm{N}_{30}$;

7. Ферментоване органічне добриво - 11 т/га (1,0 норми від вмісту $\mathrm{N}$ у варіанті 2);

8. «Азотер» 10 л/га $+\mathrm{N}_{30}$. Грунтовий покрив дослідних ділянок представлений дерновопідзолистими супіщаними грунтами.

Вирощували моркву столову сорту Гіганта. Площа посівної ділянки становила 21,0 м². Агротехніка вирощування культури $є$ загальноприй- нятою для зони західного полісся України. Досліджуване органічне добриво, що виготовлене шляхом ферментації торфу та курячого посліду, характеризується наступним хімічним складом (на суху речовину): $\mathrm{N}-1,82 \%, \mathrm{P}_{2} \mathrm{O}_{5}-1,70 \%, \mathrm{~K}_{2} \mathrm{O}$ - 1,06\%. Мікробіологічний препарат «Азотер» створений на основі азотфіксувальних бактерій Azotobacter Croococcum $\left(1,54 * 10^{10}\right.$ КУО в $\left.\mathrm{cm}^{3}\right)$ та Azospirillium Braziliense $\left(2,08 * 10^{9}\right.$ КУО в $\left.\mathrm{cm}^{3}\right)$, а також фосформобілізувальних бактерій Bacterium Megatherium $\left(1,58^{*} 10^{8}\right.$ КУО в см $\left.{ }^{3}\right)$. Використовували його шляхом передпосівної обробки грунту із наступним загортанням. Органічні та мінеральні добрива (аміачну селітру, суперфосфат гранульований та калімагнезію) вносили під основний обробіток моркви столової.

Біохімічні аналізи коренеплодів моркви проводили після збору врожаю: вміст сухої речовини згідно з ГОСТ 13586.5, вміст нітратів - ДСТУ 4948, вміст каротину - ГОСТ 13496.17.

Статистичну обробку отриманих результатів здійснювали методом дисперсійного аналізу за Б. О. Доспєховим із використанням стандартних комп'ютерних програм.

Результати досліджень. Результати проведених досліджень із вивчення впливу ферментованого добрива та мікробіологічного препарату на продуктивність моркви столової підтверджують їх ефективність. Відмічено достовірне збільшення урожайності культури на всіх варіантах протягом трьох років досліджень (2012-2014 рр.). Внесення повної норми (еквівалентної за кількістю азоту рекомендованій нормі азотних добрив) ОФД зумовлює підвищення урожайності коренеплодів на 38,4 \%. Під час поєднання половинної його норми $(5,5$ т/га) 3 мікробіологічним препаратом «Азотер» збільшення урожайності становила 35,0 \%, а за додаткового внесення аміачної селітри - 36,3 \% (табл. 1).

Варто відмітити, що вказані агроприйоми за ефективністю дії на врожайність коренеплодів моркви столової не відрізняються від традиційних органічної (перегній 18 т/га) та мінеральної $\left(\mathrm{N}_{100} \mathrm{P}_{60} \mathrm{~K}_{120}\right)$ систем удобрення, де значення приростів становили $-39,9 \%$ та $41,9 \%$. Урожайність культури у разі внесення препарату на фоні $\mathrm{N}_{30}$, хоча й була дещо нижчою у порівнянні 3 вищенаведеними варіантами, проте достовірно (на 6,9 т/га, при HIP $_{05}$ 1,6-2,2) перевищувала показники отримані на неудобреній ділянці.

Також встановлено, що досліджувані системи удобрення впливають і на біохімічні показники отриманої продукції. 
СТОРІНКА МОЛОДОГО ВЧЕНОГО

\section{1. Вилив ферментованого добрива та мікробіологічного препарату} на урожай коренеплодів моркви столової (середнє за 2012-2014 рр.)

\begin{tabular}{|c|c|c|c|c|c|c|}
\hline \multirow{2}{*}{ Варіант } & \multicolumn{3}{|c|}{ Урожайність, т/га } & \multirow{2}{*}{$\begin{array}{c}\text { Середнє, } \\
\text { т/га }\end{array}$} & \multicolumn{2}{|c|}{ Приріст } \\
\hline & $2012 \mathrm{p}$. & $2013 p$. & $2014 \mathrm{p}$. & & т/га & $\%$ \\
\hline Без добрив (контроль) & 30,1 & 26,5 & 23,1 & 26,6 & - & - \\
\hline $\mathrm{N}_{100} \mathrm{P}_{60} \mathrm{~K}_{120}$ & 42,0 & 37,6 & 33,4 & 37,7 & 11,1 & 41,9 \\
\hline Перегній - 18 т/га & 41,4 & 37,2 & 32,9 & 37,2 & 10,6 & 39,9 \\
\hline ОФД - 5,5 т/га & 36,1 & 31,8 & 27,8 & 31,9 & 5,3 & 19,9 \\
\hline ОФД - 5,5 т/га + «Азотер» & 39,9 & 35,8 & 32,0 & 35,9 & 9,3 & 35,0 \\
\hline ОФД - 5,5 т/га + «Азотер» $+\mathrm{N}_{30}$ & 40,2 & 36,2 & 32,2 & 36,2 & 9,6 & 36,3 \\
\hline ОФД - 11 т/га & 41,1 & 36,7 & 32,7 & 36,8 & 10,2 & 38,4 \\
\hline «Азотер» $+\mathrm{N}_{30}$ & 37,5 & 33,2 & 29,9 & 33,5 & 6,9 & 26,0 \\
\hline
\end{tabular}

2. Вилив ферментованого добрива та мікробіологічного препарату на біохімічні показники коренеплодів моркви столової (середнє за 2012-2014 рр.)

\begin{tabular}{|c|c|c|c|}
\hline Варіант & Каротин, мг $/ \%$ & $\begin{array}{c}\text { Суха } \\
\text { речовина, } \%\end{array}$ & Нітрати, мг/кг \\
\hline Без добрив (контроль) & 14,0 & 10,7 & 43,9 \\
\hline $\mathrm{N}_{100} \mathrm{P}_{60} \mathrm{~K}_{120}$ & 14,8 & 11,2 & 80,2 \\
\hline Перегній -18 т/га & 15,1 & 11,3 & 67,7 \\
\hline ОФД $-5,5$ т/га & 14,3 & 10,9 & 58,4 \\
\hline ОФД-5,5 т/га + «Азотер» & 14,7 & 11,1 & 64,2 \\
\hline ОФД - 5,5 т/га + «Азотер»+ $\mathrm{N}_{30}$ & 14,6 & 10,6 & 71,9 \\
\hline ОФД-11 т/га & 15,1 & 11,3 & 65,5 \\
\hline «Азотер»+ $\mathrm{N}_{30}$ & 14,2 & 10,7 & 68,6 \\
\hline НІР $_{05}$ & $0,3-0,5$ & $0,3-0,4$ & $3,2-4,0$ \\
\hline
\end{tabular}

Примітка: ГДК вмісту нітратів у коренеплодах моркви столової - 400 мг/кг

Найвищий вміст каротину - 15,1 мг $/ \%$, отримано за внесення 11 т/га ОФД та 18 т/га перегною, що на 1,1 мг $/ \%$ вище ніж на варіанті без застосування добрив (табл. 2). Сумісне застосування препарату та ОФД у нормі 5,5 т/га також стимулювало синтез каротину, та зумовило достовірне перевищення контрольних значень на 0,6-0,7 мг $/ \%$ залежно від варіанту. Обробка грунту «Азотером» на фоні аміачної селітри не сприяла суттєвому зростанню досліджуваного показника.

Важливим критерієм оцінки якості коренеплодів моркви столової є вміст сухої речовини. Єдиної думки щодо впливу удобрення на даний показник у літературі немає: деякі науковці повідомляють, що під час удобрення моркви столової накопичення сухої речовини значно підсилюється, а інші відзначають зменшення іiі вмісту з підвищенням доз добрив, особливо азотних $[1,7]$.

Згідно 3 результатами наших досліджень, 


\section{СТОРІНКА МОЛОДОГО ВЧЕНОГО}

збільшення вмісту сухої речовини в коренеплодах моркви (на 0,5-0,6 \%) характерне для варіантів внесення 11 т/га ОФД, 18 т/га перегною, $\mathrm{N}_{100} \mathrm{P}_{60} \mathrm{~K}_{120}$. Під час інтегрованого застосування «Азотеру» та 5,5 т/га ОФД суттєвого зростання вмісту сухої речовини не відмічено, а при додатковому внесенні аміачної селітри спостерігається тенденція до іiі зниження. Використання препарату на фоні аміачної селітри не мало впливу на вміст сухої речовини.

Якість моркви столової значною мірою залежить і від вмісту в коренеплодах нітратів. Досліджувані нами системи удобрення гарантували одержання продукції з меншим за максимально допустимий рівень - 400 мг/кг. Максимальне накопичення нітратів відбувалось за викорис-

\section{БІБЛІОГРАФІЯ}

1. Бикін A. B. Вплив вуглеамофоски на урожайність та показники якості продукції моркви столової / А. В. Бикін, Н. А. Пасічник // Науковий вісник НАУ. - 2000. - №32. - С. 140-146.

2. Бортнік A. M. Вплив добрив на продуктивність моркви в умовах радіоактивного забруднення / А. М. Бортнік // Вісник аграрної науки Причорномор'я. - Миколаїв : Вид-во МДАУ, 2008. - Т. 2 - Вип. 3 (46). - С. 21-25.

3. Влияние микробиологического удобрения «Байкал ЭМ-1» на продуктивность и качество столовой моркови в условиях Ленинградской области [Электронный ресурс] : практические рекомендации по применению ЭМ-технологии для выращивания корнеплодов. - Научнопроизводственное объединение «Арго-Эм». - Режим доступа : argo-shop.com.ua/library-8927.html. тання мінеральної системи удобрення, де показник їх вмісту становив 80,2 мг/кг.

Висновок. Системи удобрення із застосуванням ферментованого добрива та мікробіологічного препарату «Азотер» $\epsilon$ ефективним агрозаходом під час вирощування моркви столової й за впливом на врожайність та якість отриманої продукції не поступаються традиційним органічній і мінеральній системам. Самостійне внесення органічного ферментованого добрива (11 т/га), його поєднання (5,5 т/га) з препаратом «Азотер», а також застосування «Азотеру» в комплексі 3 $\mathrm{N}_{30}$, дає змогу підвищити урожайність культури на 26,0-38,4 \% та стимулює утворення в коренеплодах біологічно цінних речовин.

4. Гаврилюк В. А. Продуктивність сільськогосподарських культур за використання продуктів ферментації / В.А. Гаврилюк // Вісник ЦНЗ АПВ Харківської області. - 2010. - №9. C. 203-207.

5. Мельничук T. М. Ефектиність мікробних препаратів при вирощуванні овочів / Т. М. Мельничук [зб. наук. праць I3 УААН]. - К., 1994.№1. - С. 92-99.

6. Стрельцьова Т. В. Влияние биогумуса и торфогуминового удобрения на биологическую активность почвы и урожайность моркови в колочной степи Алтайского края: спец. 06.01.04 «Агрохимия» НИИ химизации Алтайского государственного аграрного университета / Т. В. Стрельцова. Барнаул, 2000. - 20 c.

7. Толстоусов В. П. Удобрения и качество урожая / В. П. Толстоусов. - М. : Колос, 1974. - 261 с. 